\title{
Integrating Straw Management and Seeding to Improve Seed Yield and Reduce Environmental Impacts in Soybean Production
}

\author{
Cailong $X u^{1}{ }^{1}$, Ruidong Li ${ }^{1,2}$, Wenwen Song ${ }^{1}$, Tingting Wu ${ }^{1}$, Shi Sun ${ }^{1} \mathbb{D}$, Weiliang Shen ${ }^{3}$, Shuixiu Hu $^{2}$, \\ Tianfu Han ${ }^{1}$ (D) and Cunxiang $\mathrm{Wu}^{1, *}$ \\ 1 Institute of Crop Sciences, Chinese Academy of Agricultural Sciences, National Soybean Industrial \\ Technology R \& D Center, Beijing 100081, China; xucailong@caas.cn (C.X.); 18511755808@163.com (R.L.); \\ songwenwen@caas.cn (W.S.); wutingting@caas.cn (T.W.); sunshi@caas.cn (S.S.); hantianfu@caas.cn (T.H.) \\ 2 School of Agronomy, Jiangxi Agricultural University, Nanchang 330045, China; hushuixiu@163.com \\ 3 Suzhou Academy of Agricultural Sciences, Suzhou 234000, China; swl21th@163.com \\ * Correspondence: wucunxiang@caas.cn; Tel./Fax: +86-10-821-058-65
}

check for

updates

Citation: Xu, C.; Li, R.; Song, W.; Wu, T.; Sun, S.; Shen, W.; Hu, S.; Han, T.; $\mathrm{Wu}, \mathrm{C}$. Integrating Straw

Management and Seeding to Improve Seed Yield and Reduce Environmental Impacts in Soybean Production. Agronomy 2021, 11, 1033. https://doi.org/10.3390/agronomy 11061033

Academic Editor: Andrea Baglieri

Received: 26 March 2021

Accepted: 19 May 2021

Published: 21 May 2021

Publisher's Note: MDPI stays neutral with regard to jurisdictional claims in published maps and institutional affiliations.

Copyright: (c) 2021 by the authors. Licensee MDPI, Basel, Switzerland. This article is an open access article distributed under the terms and conditions of the Creative Commons Attribution (CC BY) license (https:// creativecommons.org/licenses/by/ $4.0 /)$.
Abstract: Multiple cropping systems boost grain yields and have an immense potential to increase land productivity. In such cropping systems in China, soybean is directly seeded after the wheat harvest in early June. After the wheat harvest, the farmland has low amounts of soil moisture and contains large amounts of wheat straw, which negatively affect soybean growth and yields. To address these challenges, an integrated management practice (IMP) than can achieve precise direct seeding and straw mulching return, was developed. In this study, differences in the soil temperature and moisture, seedling quality, dry matter accumulation, soybean yield, and greenhouse gas emissions were investigated between IMP and the farmers' practices (FP). Compared with the FP treatment, IMP significantly increased the soil moisture and decreased the soil temperature in the topsoil layer. In addition, under the IMP treatment, the rate of emergence and developmental uniformity of soybean plants significantly increased by $21.7 \%$ and $99.5 \%$, respectively, thus increasing the leaf area index by $30.0 \%$ and dry matter accumulation by $12.0 \%$ and, in turn, increasing soybean yields by $24.7 \%$. A principal component analysis showed that the dry matter weight, relative water content, leaf area index, and developmental uniformity were strong sensitivity indices for the IMP treatment. In addition, the intensity of emission of $\mathrm{N}_{2} \mathrm{O}$ and greenhouse gases under IMP both decreased significantly by $25.1 \%$ and $28.9 \%$ compared with the FP, respectively. Thus, it was concluded that IMP is a suitable farming practice for sustainable agricultural production, and it has broad prospects for application in wheat-soybean double cropping systems in China and other similar areas globally.

Keywords: soybean; integrated management practice; yield; sustainable production

\section{Introduction}

To meet the needs of the growing global population, grain production must increase by $35-50 \%$ relative to current production, particularly in developing countries [1-3]. As an important raw material of vegetable oil and vegetable protein, more than 100 million tons of soybean are consumed per year in China. However, the yield of soybean in China is relatively low and is more than $40 \%$ lower than that in the United States [4]. Currently, the domestic production of soybeans in China cannot meet the demand for consumption, and approximately 100 million tons are imported each year [5]. Therefore, increasing the yield of soybeans and stabilizing soybean planting areas are the urgent aims for soybean production in China.

The Huang-Huai-Hai $(\mathrm{HHH})$ Plain is one of the most important food production areas in China, and more than $30 \%$ of China's soybeans are grown there [6]. In this region, winter wheat-summer soybean double cropping is commonly practiced. Under this cropping 
system, wheat is usually harvested in mid-early June, and soybean is sown directly after the wheat harvest (Figure S1). However, during this period, the temperatures are high, and there is a large amount of surface evapotranspiration [7]. Unfortunately, influenced by a monsoon climate, the rainy season has not yet arrived in the HHH region [8]. Drought stress strongly inhibits the germination of soybean seeds and the growth of seedlings, and the germination of soybean is delayed under moderate or high drought conditions $[9,10]$. The insufficient absorption of water by soybean seeds can block seed germination, which will eventually lead to a lower rate of emergence in the field [11]. Drought stress at the seedling stage can lead to the dwarfing of soybean seedlings that have a lower leaf area index and chlorophyll contents, thus affecting the accumulation of soybean biomass and soybean yields [12]. The low rate of emergence of seedlings caused by water stress can result in a population shortage in the field leading to a decline in soybean yield. Therefore, creating suitable soil moisture and ensuring that there is an adequate supply of soil water during the early stages of soybean growth are urgent aims in soybean production in the $\mathrm{HHH}$ region.

In addition, the treatment of wheat straw after the wheat harvest is also an important challenge that affects the formation of soybean yields and production input in the $\mathrm{HHH}$ region. In the winter wheat-summer soybean double cropping system, the remaining wheat straw in the field impairs the seeding of soybean, resulting in poor sowing quality, i.e., seed distance and depth can be nonuniform, and final yields can consequently be lower [13]. In the past, these problems were overcome by simply burning the straw in fields. However, the Chinese government has banned the burning of wheat straw in recent years. Accordingly, farmers have instead chosen to remove the wheat straw after the wheat has been harvested and then plant soybean seeds directly into the fields [14]. However, straw cleaning is time consuming and labor intensive and thus increases the cost of agricultural production and the number of agricultural machinery operations. In addition, the excessive use of agricultural machinery causes serious environmental pollution through the emissions of particulate matter and greenhouse gases [15]. Furthermore, unmulched topsoil always forms a crust, which further reduces the emergence and growth of soybean plants (Figure S2) $[13,16,17]$. Therefore, a convenient and efficient soybean seeding technology that improves sowing quality and reduces environmental costs is also urgently needed in the HHH region.

Many studies have confirmed that straw mulching technology can reduce the loss of soil moisture, and these techniques have been widely promoted in arid and semi-arid areas $[18,19]$. Straw mulching and simultaneously returning it to the field as the soybeans are sown can not only reduce environmental problems caused by straw treatment but also reduce the loss of soil moisture and promote soybean production in the $\mathrm{HHH}$ region. To ameliorate the negative effects of wheat straw on soybean seeding and growth in double cropping systems based on full straw retention, a novel cultivation technique was developed by the China Agriculture Research System-Soybean (CARS-Soybean) designated precise direct seeding plus straw mulching [20]. Under this new seeding practice, the wheat straw and stubble are moved laterally to cover the former seedling belts (Supplementary Video). The application of this new seeding practice has resulted in remarkably positive effects on crop yield and reduced costs and environmental damage. The average yield of soybeans reached $4630.8 \mathrm{~kg} \mathrm{ha}^{-1}$ under the new method (Table S1), which represented an increase of $133.9 \%$ compared with the average soybean yield of the HHH region (1980.0 $\mathrm{kg} \mathrm{ha}^{-1}$ ) [21]. This technology significantly reduces the number of mechanical operations and improves the efficiency of production, which is conducive to sustainable production. In addition, we hypothesized that straw mulching could reduce the soil water loss and promote the growth of soybeans and subsequent yield formation. The objectives of this study were (1) to examine the soil temperature and moisture, seedling quality, and yield formation process of soybeans under the new management practices; (2) to evaluate the crop growth parameters under different farming practices; and (3) to investigate the effect of the integrated management practice on energy conservation and a reduction in emissions. 


\section{Materials and Methods}

\subsection{Experimental Site}

Field experiments were conducted at two experimental sites in 2018-2019. In 2018, the field experiments were conducted at both the Xinxiang Experimental Station $\left(35^{\circ} 09^{\prime} \mathrm{N}\right.$, $113^{\circ} 48^{\prime}$ E) of the Institute of Crop Sciences, Chinese Academy of Agricultural Sciences, located in Xinxiang city, Henan Province and at the Suzhou Agricultural Academy $\left(33^{\circ} 44^{\prime} \mathrm{N}\right.$, $117^{\circ} 08^{\prime}$ E), Suzhou city, Anhui Province. In 2019, the field experiment was only set at the Xinxiang Experimental Station. The soil at Xinxiang is sandy loam, and the soil at Suzhou is lime concretion black soil (U.S. classification system: Typic Paleustults). Before the experiment, the organic matter, plant available nitrogen $(\mathrm{N})$, plant available phosphorous $(\mathrm{P})$, and plant available potassium $(\mathrm{K})$ in the upper $0.4 \mathrm{~m}$ of soil at the Xinxiang site were $12.9 \mathrm{~g} \mathrm{~kg}^{-1}, 63.8 \mathrm{mg} \mathrm{kg}^{-1}, 15.9 \mathrm{mg} \mathrm{kg}^{-1}$, and $112.1 \mathrm{mg} \mathrm{kg}^{-1}$, respectively. The organic matter, plant available nitrogen $(\mathrm{N})$, plant available phosphorous $(\mathrm{P})$, and plant available potassium $(\mathrm{K})$ in the upper $0.4 \mathrm{~m}$ of soil at the Suzhou site before the experiment were $10.4 \mathrm{~g} \mathrm{~kg}^{-1}, 51.5 \mathrm{mg} \mathrm{kg}^{-1}, 14.4 \mathrm{mg} \mathrm{kg}^{-1}$, and $89.2 \mathrm{mg} \mathrm{kg}^{-1}$, respectively. The monthly air temperature and rainfall during the soybean growing season are shown in Table 1.

Table 1. Mean monthly air temperature and rainfall during the 2018-2019 growing season.

\begin{tabular}{cccccc}
\hline \multirow{2}{*}{ Location } & Growing & \multicolumn{2}{c}{ Air Temperature $\left({ }^{\circ} \mathbf{C}\right)$} & \multicolumn{2}{c}{ Rainfall $(\mathbf{m m})$} \\
\cline { 3 - 5 } & Month & $\mathbf{2 0 1 8}$ & $\mathbf{2 0 1 9}$ & $\mathbf{2 0 1 8}$ & $\mathbf{2 0 1 9}$ \\
& June & 22.6 & 29.1 & 75.4 & 59.9 \\
Xinxiang, Henan & July & 27.8 & 29.7 & 78.5 & 30.8 \\
Province & August & 29.5 & 27.1 & 72.7 & 114.6 \\
& September & 29.0 & 23.0 & 35.3 & 73.5 \\
& October & 16.3 & 16.4 & 0.2 & 64.5 \\
\hline \multirow{2}{*}{ Suzhou, Anhui } & June & 26.3 & - & 69.6 & - \\
Province & July & 28.3 & - & 129.3 & - \\
& August & 27.8 & - & 452.4 & - \\
& September & 22.3 & - & 16.7 & - \\
& October & 15.9 & - & 0.6 & - \\
\hline
\end{tabular}

\subsection{Experimental Design}

At each test site, the experiments were conducted using a randomized complete block design with four replicates, and it included the following two practice patterns (Figure 1): (1) Integrated management practice (IMP), in which the soybean plants were directly seeded with a combined precision seeding and straw mulching soybean planter, which can simultaneously complete straw mulching and seeding (Figure 1A); (2) Farmers' practice $(\mathrm{FP})$, the soybean plants were seeded by a traditional soybean planter after the wheat straw was cleared from the field (Figure 1B). The seeders were calibrated to ensure that the seeding depth $(4 \pm 1 \mathrm{~cm})$ and seeding density $\left(1.8 \times 10^{5}\right.$ plants ha $\left.{ }^{-1}\right)$ were consistent between the two treatments before the seeds were sown at each experimental site. The soybean planting patterns are described in further detail in Table 2. Each plot was $72 \mathrm{~m}^{2}$ $(7.2 \mathrm{~m} \times 10 \mathrm{~m})$. The soybean variety 'Hedou19' (HD19) was selected as the experimental material at Suzhou site. 'ZhongzuoXA12938' (ZZXA12938) and 'Zhonghuang301' (ZH301) were selected as experimental materials at the Xinxiang site in 2018 and 2019, respectively. These varieties of soybean are all commonly planted locally. Soybean seeds were sown at a row spacing of $0.4 \mathrm{~m}$ in mid-June in both years. Each plot was sprayed with $30 \mathrm{~mm}$ of water immediately after sowing using a nozzle. The soybean seed was harvested in mid-October in both years. Both plots were seeded with soybeans using FP before this study. 


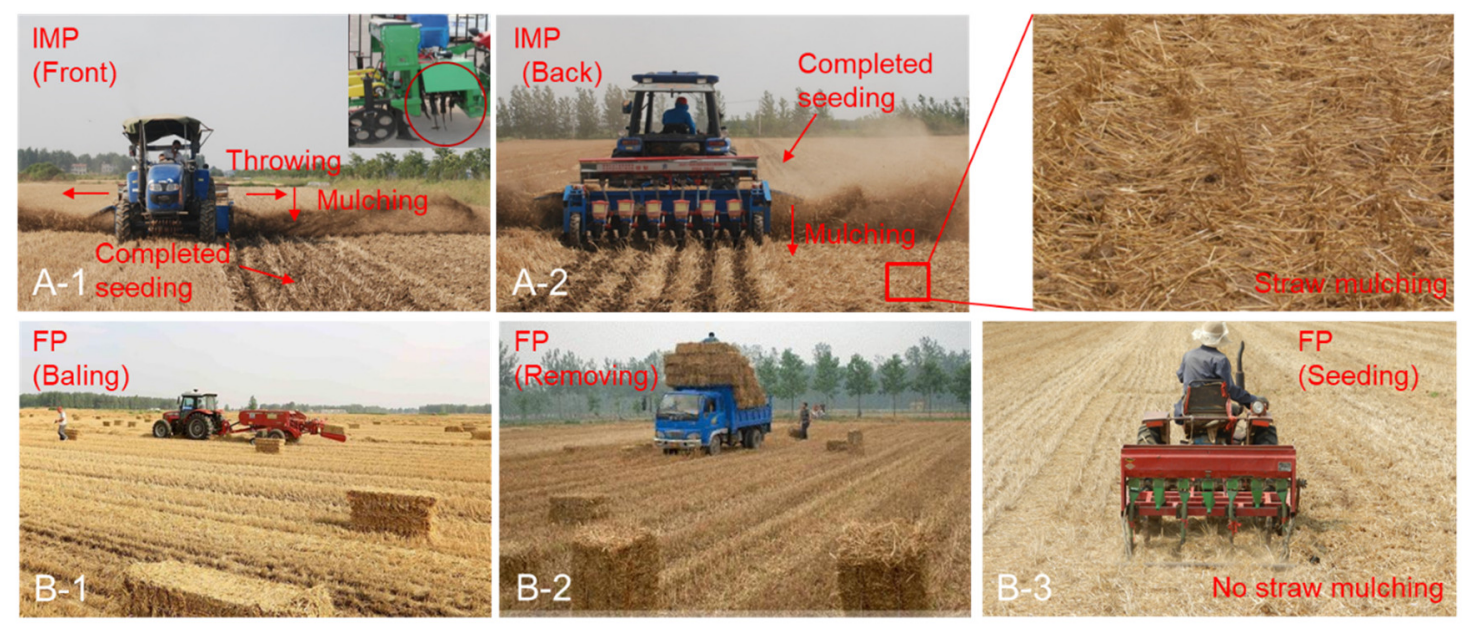

Figure 1. The operation of the two seeding management practices. IMP, integrated management practice; FP, farmers' practice. Under IMP, the seeding and straw returning treatment are completed in one operation (A). Under FP, straw baling, straw removing, and seeding are completed in three times (B).

Table 2. Description of soybean seeding management practices.

\begin{tabular}{|c|c|c|c|c|c|c|c|c|}
\hline \multirow{3}{*}{ Treatment } & & & & \multicolumn{5}{|c|}{ Agricultural Inputs } \\
\hline & \multicolumn{3}{|c|}{$\begin{array}{l}\text { Chemical Fertilizer } \\
\left(\mathrm{kg} \mathrm{ha}^{-1}\right)\end{array}$} & \multirow{2}{*}{$\begin{array}{l}\text { Pesticides } \\
\left(\mathrm{kg} \mathrm{ha}^{-1}\right)\end{array}$} & \multicolumn{3}{|c|}{$\begin{array}{l}\text { Fuel Consumption for } \\
\text { the Machinery }\left(\mathrm{kg} \mathrm{ha}^{-1}\right)\end{array}$} & \multirow{2}{*}{$\begin{array}{l}\text { Power Consumption } \\
\text { for Irrigation } \\
(\mathrm{Kw} \mathrm{h} \mathrm{ha-1)}\end{array}$} \\
\hline & $\mathbf{N}$ & $\mathrm{P}_{2} \mathrm{O}_{5}$ & $\mathrm{~K}_{2} \mathrm{O}$ & & Seeding & Straw Treatment & Harvesting & \\
\hline IMP & 75 & 100 & 75 & 5 & 36 & 0 & 40 & 552 \\
\hline FP & 75 & 100 & 75 & 5 & 30 & 50 & 40 & 552 \\
\hline
\end{tabular}

IMP, integrated management practice; FP, farmers' practice.

\subsection{Sampling and Measurements}

\subsubsection{Soil Temperature and Moisture}

The soil temperature in the top $0-5 \mathrm{~cm}$ of soil and the relative water content in the top 0-20 $\mathrm{cm}$ of the soil during the period from 2 to 5 days after seeding (DAS) were measured using a TZS-2X-G thermohygrograph (Top Instrument, Hangzhou, Zhejiang, China). The temperature probe was buried to a soil depth of $2.5 \mathrm{~cm}$, while the humidity probes were buried to a soil depth of $2.5,7.5,12.5$, and $17.5 \mathrm{~cm}$.

\subsubsection{Rate of Emergence}

Three-m-long sowing strips were selected from each plot at 6 DAS to record the number of seedlings $(S N)$ until the seedling numbers were unchanged. The rate of emergence was calculated as follows:

$$
\text { Rate of emergence }(\%)=\frac{S N}{S R} \times 100
$$

where $S R$ is the number of seeds in the sowing strips.

\subsubsection{Developmental Uniformity}

At 50 DAS, 3-m-long sowing strips were selected from each plot to record the number of expanded leaves for each soybean plant. The developmental uniformity was calculated as follows:

$$
\text { Uniformity }=\frac{\mu}{\sqrt{\frac{1}{n-1} \sum_{i=1}^{n}\left(x_{i}-\mu\right)^{2}}}
$$

where $\mu$ is the average number of expanded leaves per plant in the sample and $\mathrm{n}$ is the number of the plants in the sample. 


\subsubsection{Leaf Area Index and Dry Matter Weight}

Five plants were randomly obtained from each plot during stages R1-R8 as described by Fehr and Carviness [22]. The plants samples were obtained at the R1, R3, R5, and R7 stages. The leaf area was measured with a LI-3000C leaf area meter (Li-COR, Lincoln, NE, USA). The leaf area index (LAI) was calculated as follows:

$$
\text { LAI }=\text { leaf area } \times \frac{N}{S}
$$

where $N$ is the number of soybean plants per unit area of field and $S$ is the unit area of the field. The plants were then dried in a forced draft convection oven at $80^{\circ} \mathrm{C}$ until a constant weight was reached. The weight of seed and the other parts of the plant were determined separately.

\subsubsection{Photosynthetic Rate}

Ten plants were randomly selected from each plot at the R1, R3, R5, and R6 stages. The photosynthetic rate $\left(P_{\mathrm{n}}, \mu \mathrm{mol} \mathrm{CO} \mathrm{Cm}^{-2} \mathrm{~s}^{-1}\right)$ was measured from the middle lobules of the third leaf (from the top toward the bottom) of 10 plants in each plot at 9:00-11:00 on a sunny day with a portable photosynthesis measurement instrument (LI-6400xt, LI-COR, Lincoln, NE, USA). The chamber was equipped with a red/blue LED light source. The PAR was set at $1200 \mu \mathrm{mol} \mathrm{m}{ }^{-2} \mathrm{~s}^{-1}$. The values were measured using an open system.

\subsubsection{Yield and Yield Components}

At the harvest, soybean seed yield ( $\mathrm{kg} \mathrm{ha}^{-1}$, determined after drying to $13.5 \%$ water content) was measured from a randomly selected $2.4 \mathrm{~m}^{2}$ area of each plot. The number of harvested plants, seeds number per plant, 100-seed weight, and total seed weight per plant were also determined.

\subsubsection{Intensities of $\mathrm{N}_{2} \mathrm{O}$ and Greenhouse Gas Emission}

The direct $\mathrm{N}_{2} \mathrm{O}$ emission $\left(\mathrm{kg} \mathrm{N}^{-1}\right), \mathrm{NH}_{3}$ volatilization $\left(\mathrm{kg} \mathrm{N}\right.$ ha $\left.{ }^{-1}\right)$, and $\mathrm{NO}_{3}$ leaching $\left(\mathrm{kg} \mathrm{N} \mathrm{ha}^{-1}\right)$ were calculated according to the following formulae [23,24].

$$
\begin{gathered}
\text { Direct } \mathrm{N}_{2} \mathrm{O} \text { emission }=0.48 \mathrm{e}^{0.0058 \mathrm{X}} \\
\mathrm{NH}_{3} \text { volatilization }=0.24 \mathrm{X}+1.3 \\
\mathrm{NO}_{3^{-}} \text {leaching }=4.46 \mathrm{e}^{0.0094 \mathrm{X}}
\end{gathered}
$$

In these formulas, $\mathrm{X}$ is the $\mathrm{N}$ rate $\left(\mathrm{kg} \mathrm{N} \mathrm{ha}^{-1}\right)$. The indirect $\mathrm{N}_{2} \mathrm{O}$ emissions were estimated using the IPCC methodology (IPCC, 2006), where $1 \%$ and $0.75 \%$ of the volatilized $\mathrm{N}-\mathrm{NH}_{3}$ and leached $\mathrm{N}-\mathrm{NO}_{3}$ were assumed to be lost as $\mathrm{N}_{2} \mathrm{O}-\mathrm{N}$. The $\mathrm{N}_{2} \mathrm{O}$ emission intensity $\left(\mathrm{kg} \mathrm{N} \mathrm{Mg}^{-1}\right)$ was calculated as follows:

$$
\mathrm{N}_{2} \mathrm{O} \text { emission intensity }=\frac{\text { total } \mathrm{N}_{2} \mathrm{O} \text { emissions }}{\text { soybean yield }}
$$

Total greenhouse gas emissions ( $\mathrm{kg} \mathrm{CO}$ eq; including $\mathrm{CO}_{2}, \mathrm{CH}_{4}$, and $\mathrm{N}_{2} \mathrm{O}$ ) during soybean production were represented as three discrete components: (1) emissions associated with $\mathrm{N}$ fertilizer application; (2) emissions associated with $\mathrm{N}$ fertilizer production and transportation; and (3) emissions associated with the production and transportation of $\mathrm{P}$ and $\mathrm{K}$ fertilizers and pesticides, as well as the diesel fuel that was combusted during farming operations, such as sowing, tilling, and harvesting. The components were calculated using the following formula $[23,24]$.

Greenhouse gas emissions during $\mathrm{N}$ use $=298 \times \mathrm{N}_{2} \mathrm{O}_{\text {total }} \times 44 / 28$ 
In the formula, $\mathrm{N}_{2} \mathrm{O}_{\text {total }}\left(\mathrm{kg} \mathrm{N} \mathrm{ha}^{-1}\right)$ is the sum of direct and indirect $\mathrm{N}_{2} \mathrm{O}$ emissions. The conversion factor for $1 \mathrm{~kg}$ of $\mathrm{N}_{2} \mathrm{O}$ to an equivalent amount of $\mathrm{CO}_{2}$ is 298 . The conversion factor for $\mathrm{N}$ to $\mathrm{N}_{2} \mathrm{O}$ is $44 / 28$.

Greenhouse gas emission during $\mathrm{N}$ production $=\mathrm{N}_{\text {input }} \times 8.21$

In this formula, $\mathrm{N}_{\text {input }}$ is the amount of nitrogen applied, while 8.21 represents the greenhouse gas emissions from the production and transportation of $1 \mathrm{~kg}$ of $\mathrm{N}$.

Greenhouse gas emission during other pathways $=$

$$
\begin{aligned}
& \mathrm{P}_{2} \mathrm{O}_{5 \text { input }} \times \mathrm{EF}_{\mathrm{p}}+\mathrm{K}_{2} \mathrm{O}_{\text {input }} \times \mathrm{EF}_{\mathrm{k}} \\
& +\mathrm{Pest}_{\text {.input }} \times \mathrm{EF}_{\text {pest. }}+\text { Fuel }_{\text {input }} \times \mathrm{EF}_{\text {fuel. }}+9.2 \times \text { Irri. } \times \mathrm{EF}_{\text {elec. }}
\end{aligned}
$$

In these formulae, each variable $\mathrm{EF}$ is the emission factor of a different source of greenhouse gas emission, and the values of $\mathrm{EF}_{\mathrm{p}}, \mathrm{EF}_{\mathrm{k}}, \mathrm{EF}_{\text {pest }}, \mathrm{EF}_{\text {fuel }}$, and $\mathrm{EF}_{\text {elec. }}$ were 0.79, $0.55,19.13,3.75$, and $1.14 \mathrm{~kg} \mathrm{CO}_{2}$ eq per unit input, respectively. The greenhouse gas intensity $\left(\mathrm{kg} \mathrm{CO}_{2} \mathrm{eq} \mathrm{Mg}^{-1}\right.$ ) was calculated as follows:

$$
\text { Greenhouse gas intensity }=\frac{\text { total greenhouse gas emissions }}{\text { soybean yield }}
$$

\subsubsection{Statistical Analyses}

Statistical analyses were conducted using SPSS 17.0 (SPSS Inc., Chicago, IL, USA). The effects of the treatments on parameters measured (relative water content, rate of emergence, developmental uniformity, leaf area index, dry matter weight, yield, and yield components) were evaluated using a univariate analysis of variance (ANOVA) procedures. The difference in photosynthetic data was analyzed using a $t$ test. Differences were determined to be significant using the LSD test at a 0.05 probability level. A principal component analysis (PCA) was used to select the most appropriate crop parameters. All the figures were drawn using Sigma Plot 12.0 (SYSTAT Software Inc., San Jose, CA, USA).

\section{Results}

\subsection{Soil Temperature and Moisture}

In the present study, the soil temperature in the top $0-5 \mathrm{~cm}$ and the soil relative water content in the top $0-20 \mathrm{~cm}$ of the field were both investigated during the period from 2 to 5 DAS. At this point, we described it with the data of Xinxiang test site (Figures 2 and 3). Compared with the FP, the soil surface temperature under the IMP treatment decreased significantly, particularly between 12:00 and 18:00 each day (Figure 2). Typically, no significances in the soil relative water content were found between the two treatments at 2 DAS (Figure 3A,E). With the increase in days after sowing, the water content of 0-10 cm soil layer under IMP remained at a high level (Figure 3B,C,F,G). At 5 DAS, the relative water content of soil in the top 0-20 cm under the IMP treatment was significantly higher than that under FP with the exception of $0-5 \mathrm{~cm}$ layer in 2018.

\subsection{Rate of Emergence}

Figure 4 shows the effects of seeding management practices on the rate of emergence for soybean at Suzhou in 2018 and at Xinxiang from 2018 to 2019. The rate of emergence for soybean increased significantly under IMP condition (Figure 4). The rate of emergence for soybean under IMP increased significantly by $23.8 \%$ at Suzhou and $19.6 \%$ at Xinxiang. Accordingly, IMP promoted the rate of emergence for soybeans. Under the IMP treatment, it took six days to reach a $50 \%$ emergence rate of soybean seedling, which was a reduction in time of $14.3 \%$ at Suzhou and $13.7 \%$ at Xinxiang compared with the FP treatment. 


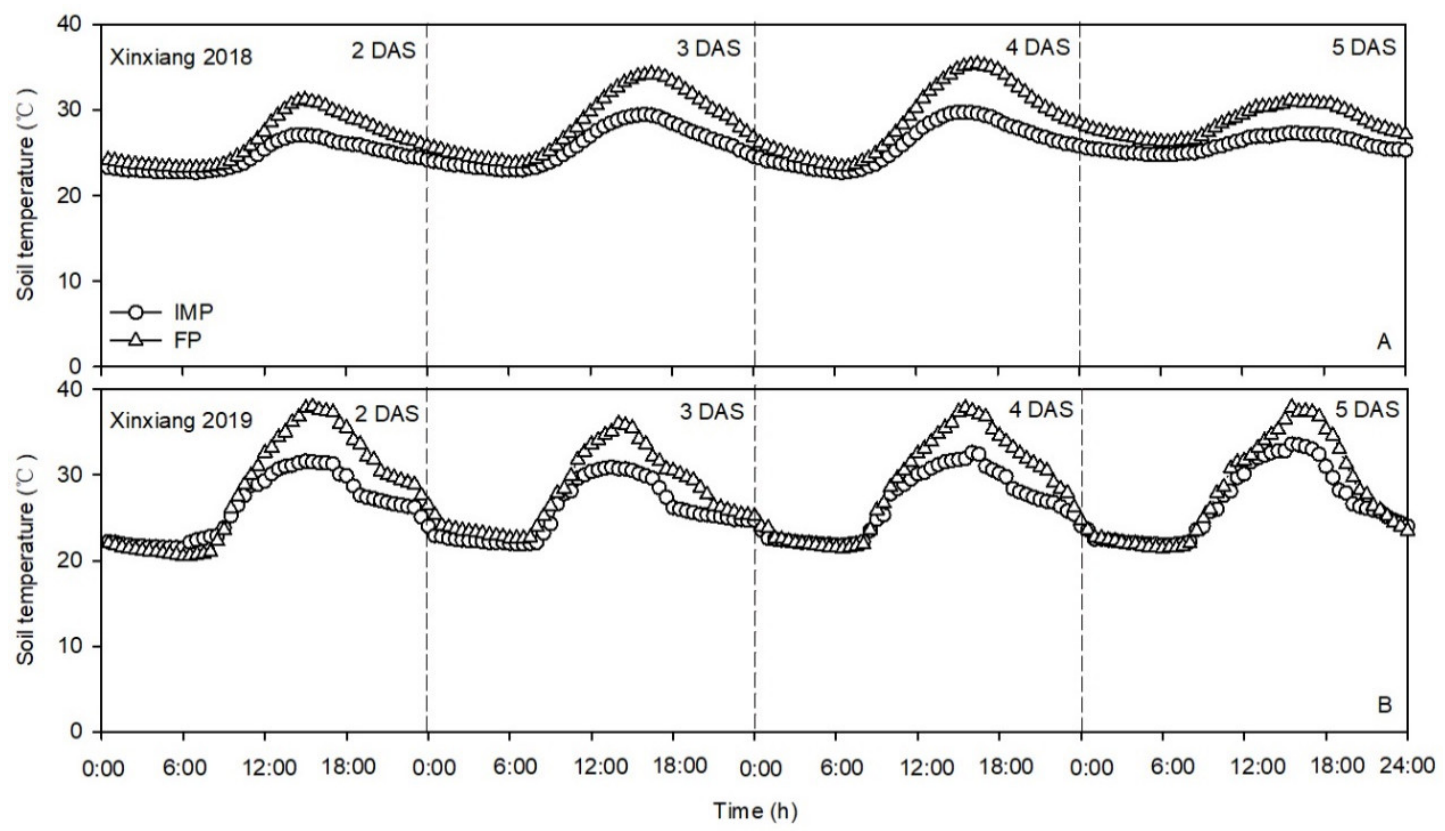

Figure 2. The effects of seeding management practices on soil temperature in the top $0-5 \mathrm{~cm}$ of the field in Xinxiang site. DAS, day after seeding. IMP, integrated management practice; FP, farmers' practice. $(\mathbf{A}, \mathbf{B})$ represent soil temperatures at Xinxiang site in 2018 and 2019, respectively.

Relative water content(\%) Relative water content(\%) Relative water content(\%) Relative water content(\%)

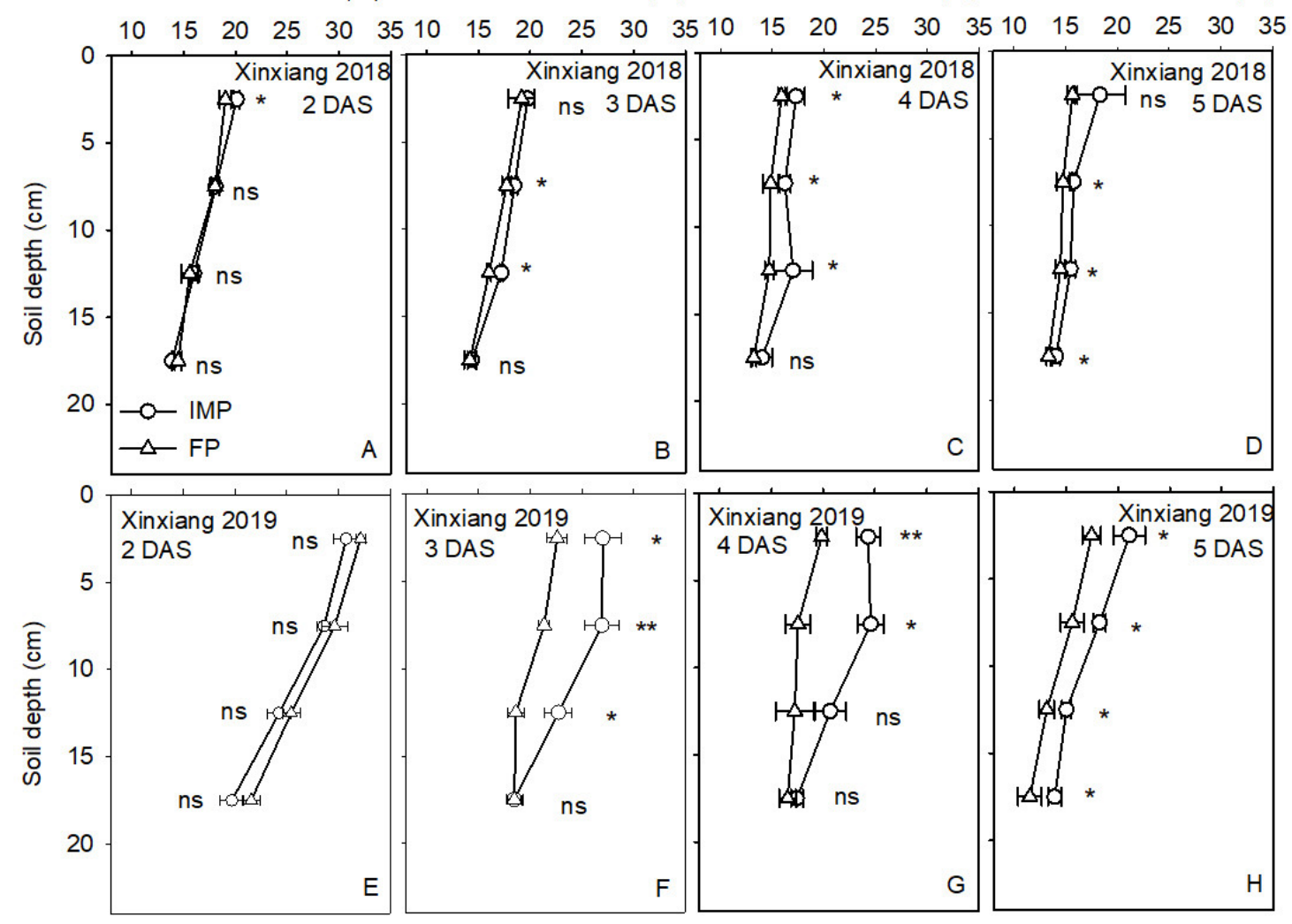

Figure 3. The effects of seeding management practices on relative water content in the top $0-20 \mathrm{~cm}$ of the field in Xinxiang site. DAS, day after seeding. IMP, integrated management practice; FP, farmers' practice. * and **, indicate significance different at the 0.05 and 0.01 probability levels, respectively, while ns indicates not significantly different. The left and right bars of each dataset represent standard error. (A-D) and (E-H) represent relative water content of soil at Xinxiang site in 2018 and 2019, respectively. 


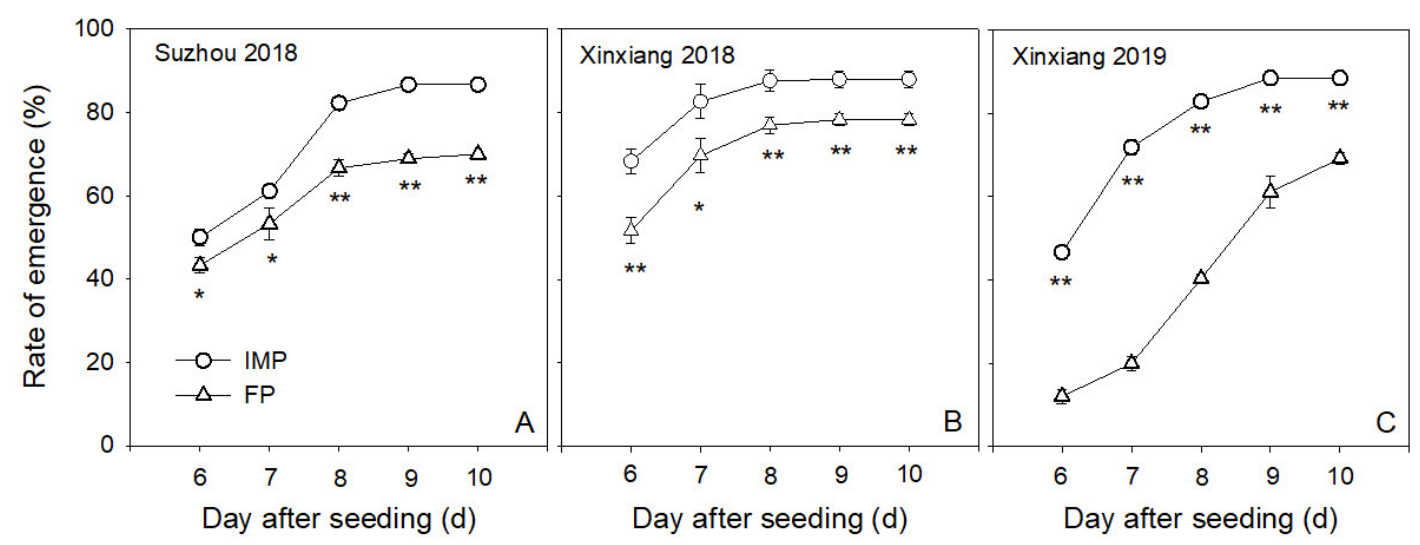

Figure 4. The effects of seeding management practices on the rate of emergence for soybean. IMP, integrated management practice; FP, farmers' practice. * and ${ }^{* *}$, indicate significance different at the 0.05 and 0.01 probability levels, respectively. The bottom and top bars of each dataset represent standard error. (A) represents the rate of emergence at Suzhou site in 2018. (B,C) represent the rate of emergence at Xinxiang site in 2018 and 2019, respectively.

\subsection{Developmental Uniformity}

The developmental process of soybean plants was investigated, and the developmental uniformity was calculated at 50 DAS. Figure 5 shows the effects of seeding management practices on the developmental uniformity for soybeans at Suzhou in 2018 and at Xinxiang from 2018 to 2019, respectively. The developmental process of soybean plants was promoted under the IMP treatment. In addition, the developmental uniformity for soybeans under IMP increased significantly by $57.4 \%$ at Suzhou and $141.5 \%$ at Xinxiang.
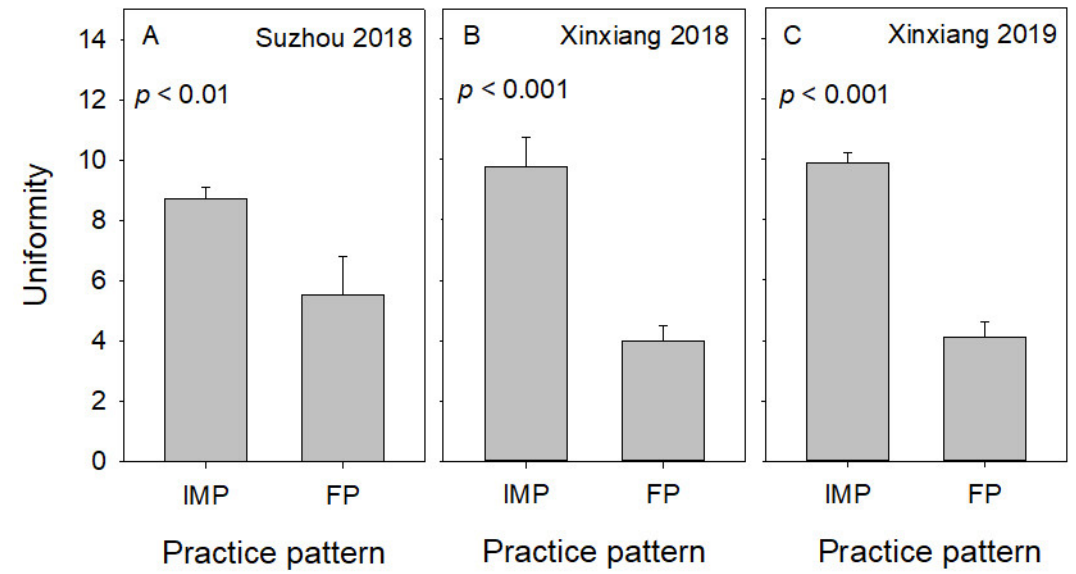

Figure 5. The effects of seeding management practices on developmental uniformity of soybean. IMP, integrated management practice; FP, farmers' practice. The bottom and top bars of each dataset represent standard error. (A) represents the developmental uniformity of soybean at Suzhou site in 2018. (B,C) represent the developmental uniformity of soybean at Xinxiang site in 2018 and 2019 , respectively.

\subsection{Leaf Area Index and Dry Matter Weight}

The leaf area index of soybean was investigated after the flowering stage. The leaf area index of soybean generally exhibited unimodal curves with peaks between the R3 and R5 periods (Figure 6A-C). Compared with the FP treatment, IMP significantly increased the leaf area index of soybean plants. The leaf area index of soybean under IMP was significantly increased by 20.8\% (mean after flowering) at Suzhou in 2018 and $38.2 \%$ (mean after flowering) at Xinxiang in 2018 and 2019 on average. 

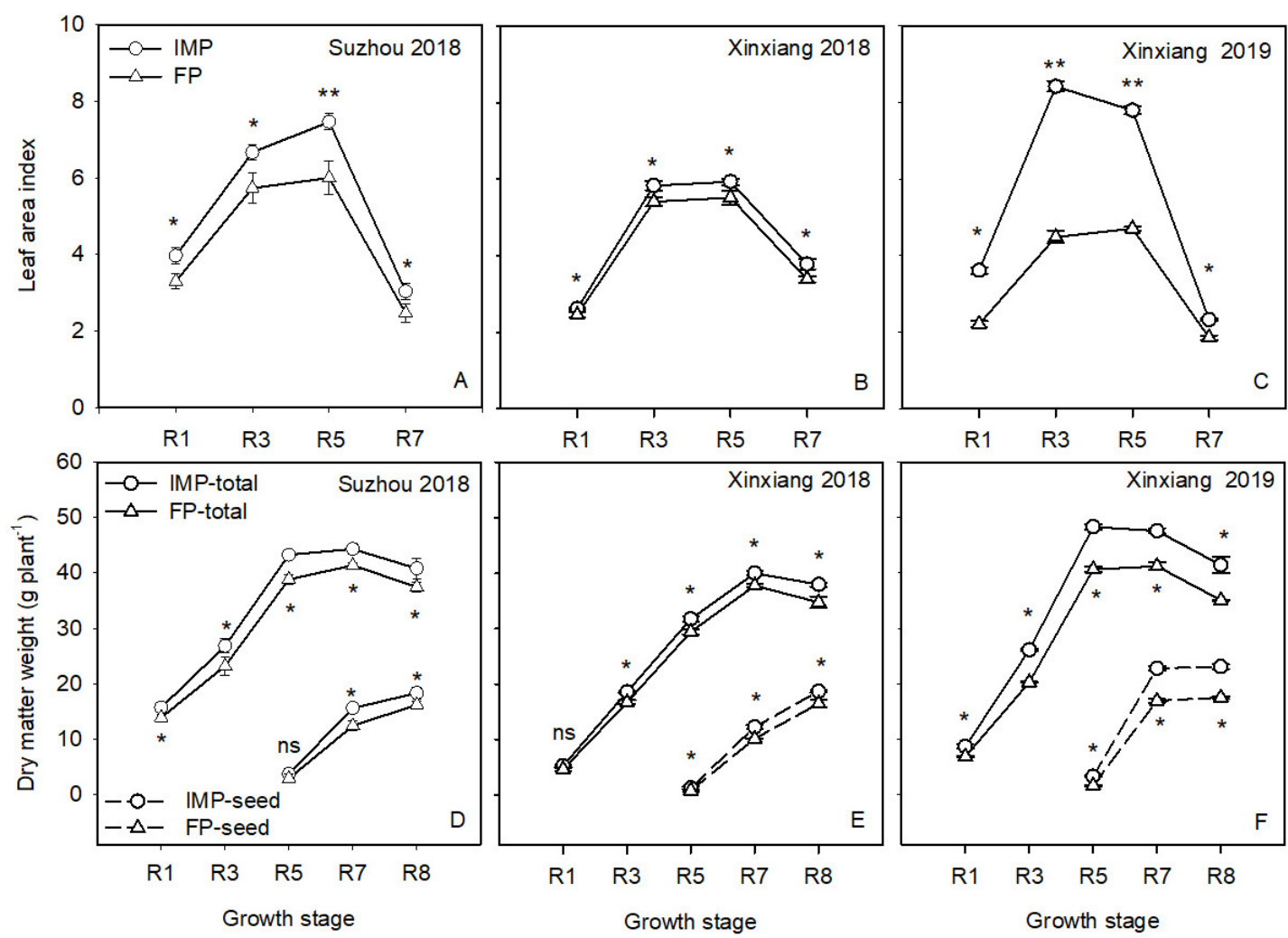

Figure 6. The effects of seeding management practices on leaf area index and dry matter weight for soybean. IMP, integrated management practice; FP, farmers' practice. * and **, indicate significance different at the 0.05 and 0.01 probability levels, respectively. Ns indicates not significant different. The bottom and top bars of each dataset represent standard error. (A) represents the leaf area index of soybean at Suzhou site in 2018. (B,C) represent the leaf area index of soybean at Xinxiang site in 2018 and 2019, respectively. (D) represents the dry matter weight of soybean at Suzhou site in 2018. (D,F) represent the dry matter weight of soybean at Xinxiang site in 2018 and 2019, respectively.

The total dry matter weight and seed dry matter weight of soybean were both investigated after the flowering stage. The total dry matter weight of soybean plants increased gradually after the R1 stage, as well as the seed weight, after the R5 stage (Figure 6D-F). Moreover, the total dry weight of soybean decreased at the R8 stage because the leaves began to fall off after R7 stage. Compared with the FP treatment, IMP significantly increased the total biomass after R3 stage and seed weight after R5 stage. At the R8 stage, the total biomass and seed weight under IMP treatment increased significantly by $12.0 \%$ and $19.4 \%$ on average, respectively, compared with the values under FP conditions.

\subsection{Photosynthetic Rate}

In the present study, the photosynthetic rate of soybean was investigated during the period from R1 to R6. Here, we present the data of Xinxiang test site (Figure 7). The $P_{\mathrm{n}}$ of soybean remained at a high level before the R5 stage, while it decreased after the R5 stage. Under the IMP treatment, the $P_{\mathrm{n}}$ of soybean was significantly higher (by $27.7 \%$ on average of two years) than that under the FP condition of period from R1 to R6 stages. In addition, the $P_{\mathrm{n}}$ of soybean decreased slowly during the period from R5 to R6 under IMP (by 52.3\%) compared with the FP treatment (by 54.2\%).

\subsection{Yield and Yield Components}

Experimental site and practice patterns had significant effects on seed yield and yield components (Table 3). The yield of soybean at the Xinxiang site was $4190.2 \mathrm{~kg} \mathrm{ha}^{-1}$ on average, which was significantly higher by $29.5 \%$ than that under the Suzhou site $\left(3236.0 \mathrm{~kg} \mathrm{ha}^{-1}\right)$. Compared with the FP treatment, seed yield, harvesting density, and 
seeds per plant under IMP significantly increased by $24.70 \%, 19.28 \%$, and $18.84 \%$ on average, respectively. No significant differences in the 100-seed weight were found between the two practice patterns at the Suzhou site, while the 100-seed weight under IMP treatment were significantly higher than those under FP at the Xinxiang site.

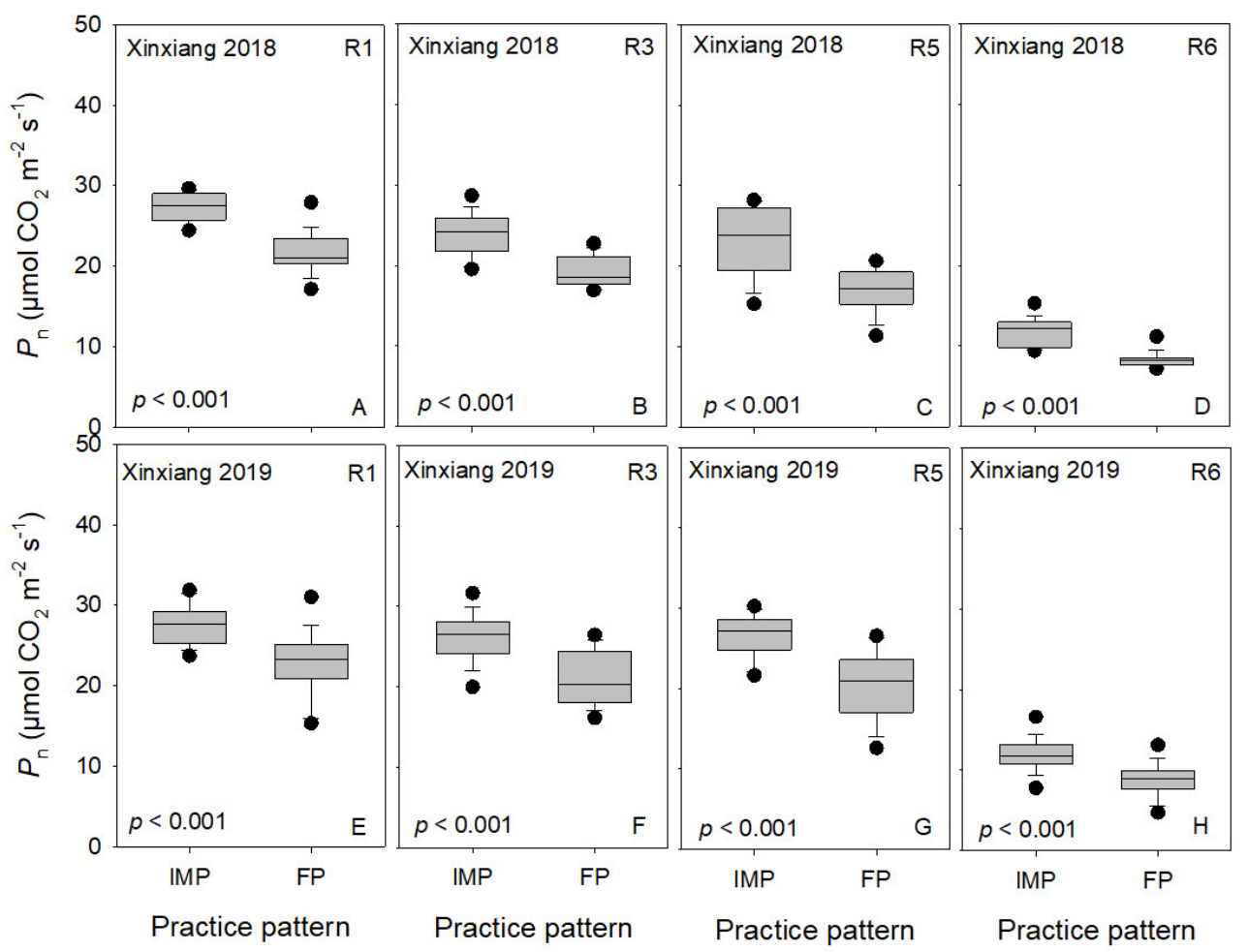

Figure 7. The effects of seeding management practices on photosynthetic rate $\left(P_{n}\right)$ for soybean. IMP, integrated management practice; FP, farmers' practice. The upper and lower box edges of the box represent the 25th and 75th percentiles of all the data, respectively; the bottom and top bars represent the 5th and 95th percentiles, respectively; the solid black dots are outlier. (A-D) and (E-H) represent $P_{\mathrm{n}}$ of soybean at Xinxiang site in 2018 and 2019, respectively.

Table 3. The effects of seeding management practices on soybean yield and yield components.

\begin{tabular}{|c|c|c|c|c|c|c|c|}
\hline \multirow{2}{*}{ Year } & \multirow{2}{*}{ Exp. Site } & \multirow{2}{*}{$\begin{array}{l}\text { Practice } \\
\text { Pattern }\end{array}$} & \multicolumn{2}{|c|}{ Plant Density $\left(10^{4}\right.$ plant ha $\left.^{-1}\right)$} & \multirow{2}{*}{$\begin{array}{l}\text { Seeds Per } \\
\text { Plant (No.) }\end{array}$} & \multirow{2}{*}{$\begin{array}{l}\text { 100-Seed } \\
\text { Weight (g) }\end{array}$} & \multirow{2}{*}{$\begin{array}{c}\text { Yield } \\
\left(\mathrm{kg} \mathrm{ha}^{-1}\right)\end{array}$} \\
\hline & & & Seeding & Harvesting & & & \\
\hline \multirow[t]{2}{*}{2018} & Suzhou, & IMP & 24.0 & $22.4 \mathrm{a}$ & $65.8 \mathrm{a}$ & $23.7 \mathrm{a}$ & $3800.9 \mathrm{a}$ \\
\hline & Anhui Province & $\mathrm{FP}$ & 24.0 & $18.6 \mathrm{~b}$ & $48.8 \mathrm{~b}$ & $22.8 \mathrm{a}$ & $2671.0 \mathrm{~b}$ \\
\hline \multirow[t]{2}{*}{2018} & Xinxiang, & IMP & 27.0 & $22.7 \mathrm{a}$ & $124.8 \mathrm{a}$ & $15.8 \mathrm{a}$ & $4356.6 \mathrm{a}$ \\
\hline & Henan Province & $\mathrm{FP}$ & 27.0 & $20.6 \mathrm{~b}$ & $114.1 \mathrm{~b}$ & $15.3 \mathrm{~b}$ & $3694.3 \mathrm{~b}$ \\
\hline \multirow[t]{2}{*}{2019} & Xinxiang, & IMP & 29.4 & $26.0 \mathrm{a}$ & $107.8 \mathrm{a}$ & $21.6 \mathrm{a}$ & $4735.9 \mathrm{a}$ \\
\hline & Henan Province & $\mathrm{FP}$ & 29.4 & $20.4 \mathrm{~b}$ & $88.3 \mathrm{~b}$ & $20.3 \mathrm{~b}$ & $3973.8 \mathrm{~b}$ \\
\hline \multicolumn{4}{|c|}{ Analysis of variance } & \multicolumn{4}{|c|}{ F value } \\
\hline \multicolumn{4}{|c|}{ Exp. site (E) } & $303.6^{* * *}$ & $1133.9^{* * *}$ & $537.8 *$ & $208.8^{* * *}$ \\
\hline \multicolumn{4}{|c|}{ Treatment(T) } & $26.0^{* * *}$ & $85.1^{* * *}$ & $54.9 *$ & $55.5^{* * *}$ \\
\hline \multicolumn{3}{|c|}{$\mathrm{E} \times \mathrm{T}$} & & $8.8^{* *}$ & $5.5^{*}$ & $1.8^{\mathrm{ns}}$ & $6.2 *$ \\
\hline
\end{tabular}

Values followed by the same letter within a column and year are not significantly different at $p<0.05$ as determined by the LSD test. IMP, integrated management practice; FP, farmers' practice. ${ }^{*}, * *$, and ${ }^{* * *}$ indicate significance different at the $0.05,0.01$, and 0.001 probability levels, respectively, while ${ }^{\mathrm{ns}}$ indicates not significant different. Different letters within the values in each year indicate significant differences at the 0.05 probability level. 


\subsection{Greenhouse Gas Emissions}

In the present study, the greenhouse gas emissions under different practice patterns were calculated. Under the IMP model, the intensity of $\mathrm{N}_{2} \mathrm{O}$ and greenhouse gas emissions both significantly decreased at the two experimental sites as the production inputs of soybeans were significantly reduced (Table 2, Figure 8). Compared with the FP model, the intensity of $\mathrm{N}_{2} \mathrm{O}$ emissions under IMP conditions decreased by $31.6 \%$ at Suzhou and $18.5 \%$ at Xinxiang (Figure $8 \mathrm{~A}-\mathrm{C}$ ). In addition, the intensity of greenhouse gases under IMP condition decreased significantly by $36.3 \%$ at Suzhou and $21.6 \%$ at Xinxiang compared with the FP model (Figure 8D-F).
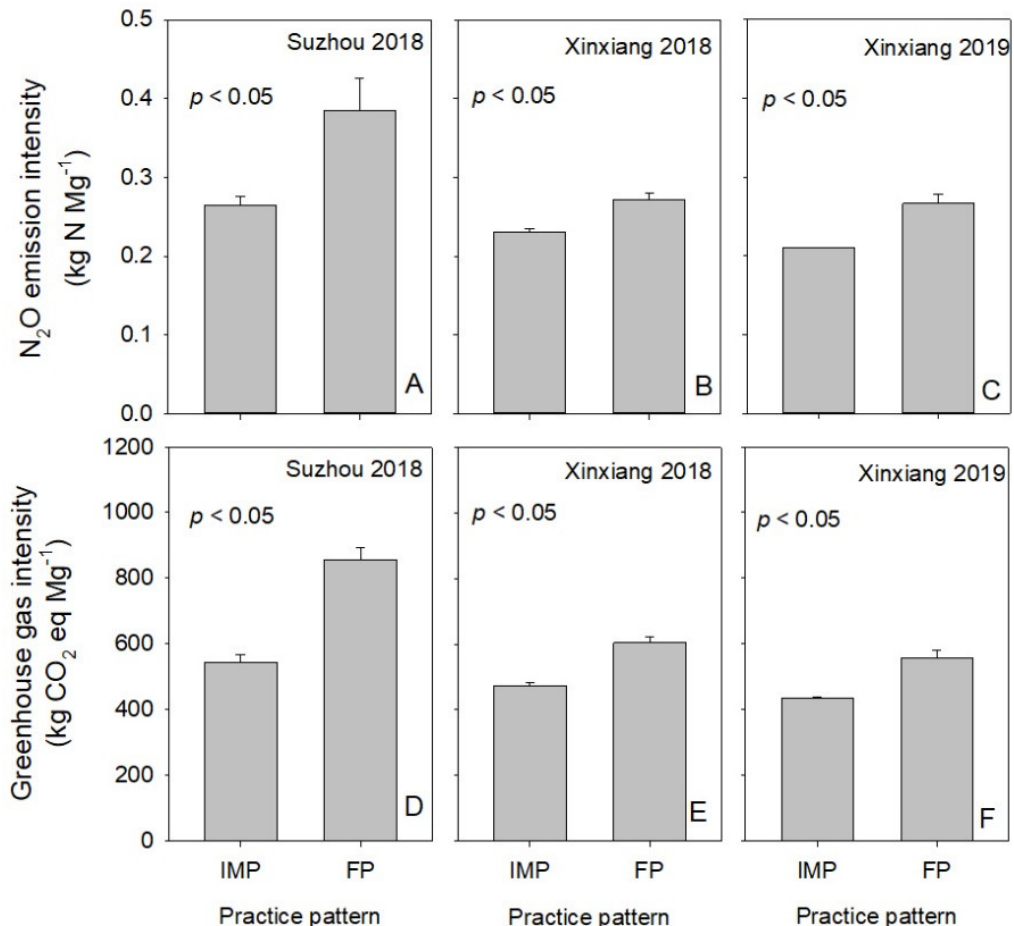

Figure 8. The effects of seeding management practices on $\mathrm{N}_{2} \mathrm{O}$ emission intensity and greenhouse gas intensity of soybean production. IMP, integrated management practice; FP, farmers' practice. The bottom and top bars of each dataset represent standard error. (A) represents the $\mathrm{N}_{2} \mathrm{O}$ emission intensity at Suzhou site in 2018. (B,C) represent the $\mathrm{N}_{2} \mathrm{O}$ emission intensity at Xinxiang site in 2018 and 2019, respectively. (D) represents the greenhouse gas intensity at Suzhou site in 2018. (E,F) represent the greenhouse gas intensity at Xinxiang site in 2018 and 2019, respectively.

\subsection{Principal Component Analysis}

Crop parameters under the two practice patterns were evaluated by PCA in the present study. In the PCA, the two principal components (PC1 and PC2) were selected, since they each had eigenvalues greater than 1 and together explain $93.593 \%$ of the total variance, which thus effectively represents the original eight parameters (Table 4). PC1 had an eigenvalue of 6.360 and explained $79.502 \%$ of the variance, while PC2 had an eigenvalue of 1.127 and explained $14.091 \%$ of the variance. Figure 9 shows the sensitivity indices for the two practice patterns. In the present study, the dry matter weight, relative water content, leaf area index, and developmental uniformity were strongly sensitive indices of IMP. 
Table 4. Results of the principal component analysis (PCA) about eight crop parameters.

\begin{tabular}{cccc}
\hline Parameters & \multicolumn{2}{c}{ PCA } & \multirow{2}{*}{ Communality } \\
\cline { 2 - 3 } & PC1 & PC2 & \\
\hline Photosynthetic rate $\left(\mu \mathrm{mol} \mathrm{CO}_{2} \mathrm{~m}^{-2} \mathrm{~s}^{-1}\right)$ & 0.926 & 0.293 & 0.943 \\
Leaf area index & 0.877 & -0.223 & 0.818 \\
Developmental uniformity & 0.997 & -0.059 & 0.998 \\
Development rate & 0.299 & 0.953 & 0.996 \\
Emergence rate & 0.950 & 0.126 & 0.918 \\
Surface temperature $\left({ }^{\circ} \mathrm{C}\right)$ & -0.985 & 0.162 & 0.996 \\
Dry matter weight $(\mathrm{g})$ & 0.898 & -0.121 & 0.820 \\
Relative water content $(\%)$ & 0.986 & -0.156 & 0.997 \\
Principal component eigenvalue & 6.360 & 1.127 & \\
Variance explained $(\%)$ & 79.502 & 14.091 & \\
Cumulative variance explained $(\%)$ & 79.502 & 93.593 & \\
\hline
\end{tabular}

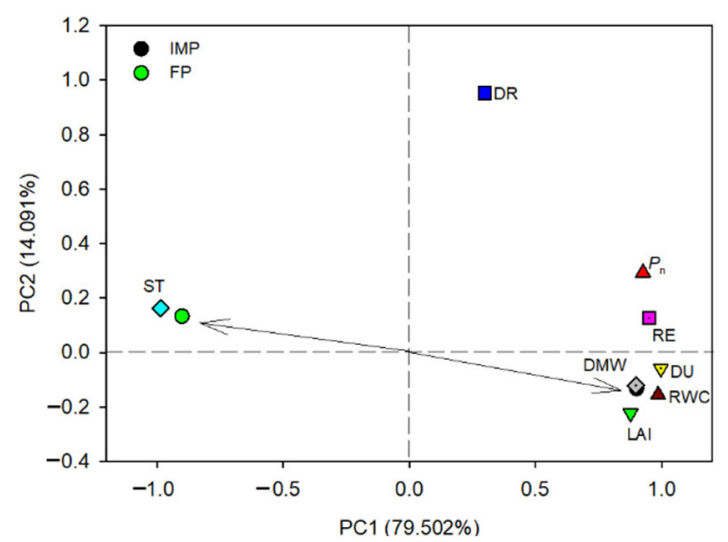

Figure 9. Sensitivity indexes under different management practice $\left(P_{\mathrm{n}}\right.$, photosynthetic rate; LAI, leaf area index; DU, developmental uniformity; DR, development rate; RE, rate of emergence rate; $\mathrm{ST}$, soil temperature; DMW, dry matter weight; RWC, relative water content).

\section{Discussion}

\subsection{Integrated Management Practice Optimized Soil Temperature and Soil Water Content}

Double-cropping systems in which soybean is planted after the harvest of wheat within a single year have the potential to increase production and sustainability, which are widely shared goals around the world, particularly in the Americas and Asia [25-29]. In the $\mathrm{HHH}$ region, the wheat is often harvested in hot weather with little rain, and the content of soil moisture is low, which limits the emergence of soybean plants [28,30-32]. In addition, because of the high planting density and high population biomass of wheat crops, there is more residue in the fields after wheat harvest, which is not conducive to soybean sowing, resulting in poor sowing quality when direct seeding methods are used [26,28,33]. However, clearing straw from the fields not only increases the production costs but also causes the ground to be bare, thereby increasing the evaporation of soil water, which further hinders the emergence and growth of soybean plants [32,34,35].

In the present study, the soil water content in the top $0-20 \mathrm{~cm}$ of soil under IMP was significantly higher than that under FP on average, primarily as a consequence of straw mulching (Figure 3), which was consistent with the findings of Chang et al. [36] and Deng et al. [37] in the Loess Plateau of China and those of Singh et al. [38] in a subtropical region of India. First, IMP decreased the soil temperature by reducing direct solar radiation owing to the straw mulching (Figure 2), thus reducing the evaporation of soil water. Alternatively, the soil porosity improved under straw mulching, which increased the infiltration of rainwater into soil, thus improving the capacity of soil water storage $[39,40]$. When the soil temperature is consistently above $35^{\circ} \mathrm{C}$, root activity and the antioxidant metabolism of crops are inhibited [41]. Under IMP treatment, straw mulching increased 
the relative water content and reduced the soil temperatures (Figures 2 and 3). Thus, the rate of emergence of soybean plants under IMP increased significantly (Figure 4). Based on the PCA, the dry matter weight, relative water content, leaf area index, and developmental uniformity were strong sensitivity indices for the IMP, which was confirmed in the results described above (Figure 9).

\subsection{Integrated Management Practice Promoted Soybean Growth and Yield}

In the present study, IMP improved nearly all the plant parameters according to the statistically significant differences that were observed. A significant positive correlation has been observed between crop growth uniformity and crop yield, which was subsequently verified in the productivity of soybean [32], maize [42], and wheat [43]. Under IMP, the developmental uniformity of soybeans increased significantly (Figure 5), which was associated with the improvement in soil moisture and moderate temperatures [44-46]. Continuous soil moisture and well grown soybean crops result in favorable plant growth conditions as well as higher LAI and $P_{\mathrm{n}}$, which increased the accumulation of dry matter (Figures 6 and 7).

Appropriate soil density is also required for crop growth [47-49]. Straw mulching can reduce the soil bulk density of the top $0-5 \mathrm{~cm}$ of soil, but it does not affect the 5-15 and 15-25 cm deep soil layers [50]. After long-term straw mulching, the soil bulk density of the top $0-5 \mathrm{~cm}$ soil layer can be reduced to $1.27-1.32 \mathrm{~g} \mathrm{~cm}^{-3}$, reaching a soil density level known to be ideal for crop growth [51]. Furthermore, our previous studies have also shown that straw mulching effectively alleviates the adverse effects on topsoil caused by rainfall (e.g., soil impaction and runoff compaction), reduces the phenomenon of soil crust formation after rain, and is thus conducive to the emergence and growth of soybeans $[13,28]$. In summary, the IMP treatment with straw mulching at its core optimized the topsoil environment and promoted the growth and yield of soybean.

Crop straw mulching techniques have been widely used in arid and semi-arid regions to improve crop yields $[38,46,52,53]$. In a study conducted in a semi-arid region, Chang et al. [36] showed that straw strip mulching increased the yields of potato by $22.3 \%$ on average compared with traditional practices (bare soil). Under straw mulching, the soybean yields also increased significantly by $20.8 \%$ [46]. In the present study, IMP increased the yield of grain by $24.7 \%$ at two different sites compared with the FP treatment, which confirmed the beneficial effects of straw mulching [28,32,46]. The decrease of living plants was caused by the low rate of emergence of the crop and plant death owing to diseases and particularly pests [54]. Insufficient soil water supply during emergence in the seedling period is also one of the main reasons for rates of poor emergence in soybean crops $[13,32,42]$. The IMP treatment significantly increased harvest density and seeds per plant, which were responsible for the higher soybean yield (Table 3). In the present study, the suitable soil moisture and temperature achieved under straw mulching significantly increased the rate of emergence (Figure 4), which strongly supported the survival of an adequate number of plants to harvest (Table 3). In addition, straw mulching can also enhance the soil microbial community and improve soil fertility [55-57]. Wang et al. [58] and Zhang et al. [59] reported that straw mulching stimulates soil microbial activity and improves the microbial biomass carbon and microbial activity, which both improve the sustainable production capacity of cropland soil. The supportive root layer environment that benefitted from straw mulching under IMP promoted the accumulation of soybean dry matter, while reducing the rate of pod shedding, thus increasing the number of seeds per plant (Table 3) $[36,60]$. These two main yield components (harvest density and seeds per plant) together had an increased effect on the yield of soybeans grains under IMP. Furthermore, the current straw mulching technology has mostly been developed for strip covering, in which the straw from the former crop only covers the soil between the rows of the later crop $[36,53]$. However, the IMP treatment in the present study can evenly distribute the straw on the ground (i.e., using straw to cover both the rows and seedling belts), which further enhanced the ability of straw to cover the soil. 


\subsection{Integrated Management Practice Can Reduce Greenhouse Gas Emissions}

The increasing concentration of greenhouse gases (e.g., $\mathrm{CO}_{2}, \mathrm{CH}_{4}$, and $\mathrm{N}_{2} \mathrm{O}$ ) in the atmosphere is the main cause of climate warming, with the greenhouse gases associated with agricultural production comprising $10-20 \%$ of the total [23,61]. In agricultural production, soil respiration, fertilizer and pesticide inputs, and the fuel combustion of agricultural machinery all produce greenhouse gases [24,62]. Chen et al. [63] determined that integrated soil-crop system management that used advanced crop and nutrient management can produce more grain with lower environmental costs. In addition to the selection of high-yield varieties and the optimal application of fertilizers and pesticides, light and simplified farming practices can also reduce greenhouse gas emissions by reducing the consumption of diesel and electricity $[64,65]$. Under traditional farming practices (i.e., FP), a large quantity of manpower and machinery are invested in the processes of straw cleaning before seeding (Figure 1, Table 2). Under IMP, a clean seedbed was created by simply laterally casting the straw; moreover, the straw moved along the ground served as mulch once the seeds had been planted (Supplementary Video; Figure 1). Thus, the lateral movement of straw enabled both precise seeding and straw mulching. Furthermore, this work was conducted in a single operation, which reduced the straw handling procedures and resulted in both energy savings and reductions in emission. In the present study, the intensity of $\mathrm{N}_{2} \mathrm{O}$ and greenhouse gas emissions associated with IMP were significantly lower than those under FP (Figure 9), which confirmed the above conclusion. Thus, this new cultivation methodology can reduce production costs and relieve environmental pressures, thereby contributing to sustainable agricultural production.

\section{Conclusions}

Compared with traditional soybean agricultural practices, IMP significantly increased the rate of emergence and uniform growth of soybean plants. This is owing to the beneficial soil moisture and temperature under straw mulching. Simultaneously, the yield of seed increased by $24.7 \%$ on average, which can be attributed to the increase in numbers of surviving plants and seeds per plant. In addition, the new cultivation practice reduced the intensity of $\mathrm{N}_{2} \mathrm{O}$ and greenhouse gas emissions, relieving environmental pressures. Overall, IMP is a suitable farming practice for sustainable agricultural production (Figure 10), and it has broad prospects for application in wheat-soybean double cropping systems in China and other similar areas throughout the world.

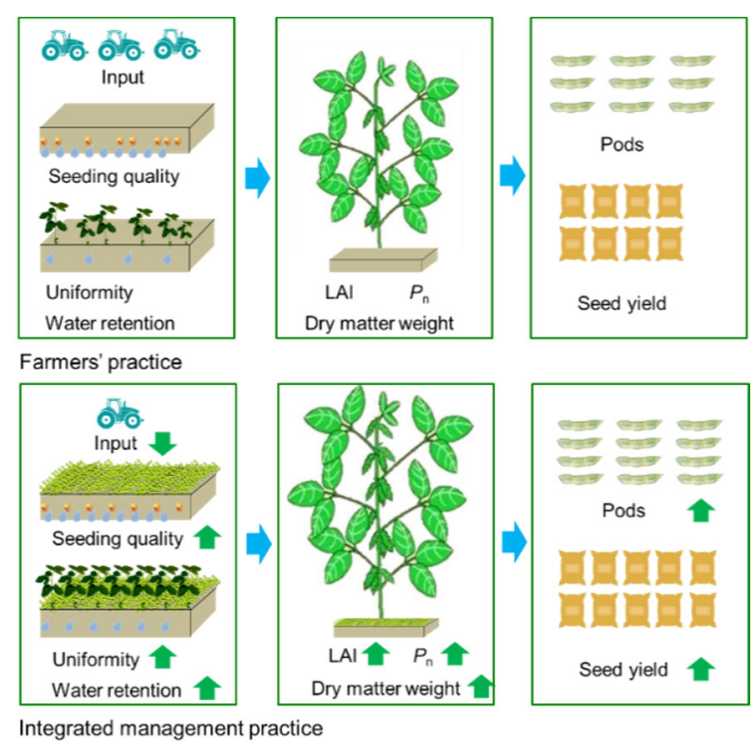

Figure 10. A contrastive diagram for the two seeding management practices in soybean productivity. LAI, leaf area index. $P_{\mathrm{n}}$, photosynthetic rate. 
Supplementary Materials: The following are available online at https://www.mdpi.com/article/10 .3390 /agronomy11061033/s1, Figure S1: The winter wheat-summer soybean double cropping system in the Huang-Huai-Hai region of China. Figure S2: Soil crust and soybean seedlings. Table S1: The soybean yield of fields using precise direct seeding plus straw mulching cultivation technique in demonstration plots in the Huang-Huai-Hai region.

Author Contributions: Conceptualization, T.H. and C.W.; methodology, C.X. and R.L.; software, C.X. and R.L.; validation, S.S., T.H. and C.W.; formal analysis, C.X., R.L., W.S. (Wenwen Song), T.W.; investigation, C.X. and R.L.; resources, S.S., W.S. (Weiliang Shen), S.H., T.H. and C.W.; data curation, C.X. and R.L.; writing-original draft preparation, C.X.; writing-review and editing, C.X. and R.L.; visualization, C.X. and R.L.; supervision, T.H. and C.W.; project administration, T.H. and C.W.; funding acquisition, T.H. and C.W.; All authors have read and agreed to the published version of the manuscript.

Funding: This work was supported by the National Key Research and Development Program of China (2020YFD1000902) and China Agriculture Research System (CASR-04).

Institutional Review Board Statement: Not applicable.

Informed Consent Statement: Not applicable.

Data Availability Statement: The data presented in this study are available on request from the corresponding author.

Conflicts of Interest: The authors declare no conflict of interest.

\section{References}

1. Tester, M.; Langridge, P. Breeding Technologies to Increase Crop Production in a Changing World. Science 2010, 327, 818-822. [CrossRef]

2. Tilman, D.; Balzer, C.; Hill, J.; Befort, B.L. Global food demand and the sustainable intensification of agriculture. Proc. Natl. Acad. Sci. USA 2011, 108, 20260-20264. [CrossRef] [PubMed]

3. Zhang, J. China's success in increasing per capita food production. J. Exp. Bot. 2011, 62, 3707-3711. [CrossRef] [PubMed]

4. Food and Agriculture Organization of the United Nations. 2021. Available online: http://www.fao.org/faostat/en/\#data/QC (accessed on 20 May 2021).

5. USAD-FAS, China: Oilseeds and Products Annual. Foreign Agricultural Service. 2021. Available online: https://www.fas.usda. gov / data/china-oilseeds-and-products-annual-6 (accessed on 18 March 2021).

6. Shan, L.; Wu, P.; Kang, S.; Feng, H.; Zhang, S. Study on agricultural water-saving countermeasures and feasibility of imple-menting semi-dry land farming in the Huang-Huai-Hai Region. Eng. Sci. 2011, 13, 37-41.

7. Xu, C.; Zhao, H.; Zhang, P.; Wang, Y.; Huang, S.; Meng, Q.; Wang, P. Delaying wheat seeding time and maize harvest improved water use efficiency in a warm temperature continental monsoon climate. Agron. J. 2018, 110, 1420-1429. [CrossRef]

8. Li, L.; Tilman, D.; Lambers, H.; Zhang, F. Plant diversity and overyielding: Insights from belowground facilitation of intercropping in agriculture. New Phytol. 2014, 203, 63-69. [CrossRef] [PubMed]

9. Wei, W.; Li, Q.-T.; Chu, Y.-N.; Reiter, R.J.; Yu, X.-M.; Zhu, D.-H.; Zhang, W.-K.; Ma, B.; Lin, Q.; Zhang, J.-S.; et al. Melatonin enhances plant growth and abiotic stress tolerance in soybean plants. J. Exp. Bot. 2015, 66, 695-707. [CrossRef]

10. Zou, J.; Jin, X.; Zhang, Y.; Ren, C.; Zhang, M.; Wang, M. Effects of melatonin on photosynthesis and soybean seed growth during grain filling under drought stress. Photosynthetica 2019, 57, 512-520. [CrossRef]

11. Zhang, M.; He, S.; Zhan, Y.; Qin, B.; Jin, X.; Wang, M.; Zhang, Y.; Hu, G.; Teng, Z.; Wu, Y. Exogenous melatonin reduces the inhibitory effect of osmotic stress on photosynthesis in soybean. PLoS ONE 2019, 14, e0226542. [CrossRef]

12. Cao, L.; Jin, X.; Zhang, Y. Melatonin confers drought stress tolerance in soybean (Glycine max L.) by modulating photosynthesis, osmolytes, and reactive oxygen metabolism. Photosynthetica 2019, 57, 812-819. [CrossRef]

13. $\mathrm{Wu}, \mathrm{T}$; $\mathrm{Wu}, \mathrm{C}$. The influence of soil crusting on emergence of soybean and its key solution in Huang-Huai-Hai River Valley. Soybean Sci. 2017, 36, 813-817.

14. Hong, J.; Ren, L.; Hong, J.; Xu, C. Environmental impact assessment of corn straw utilization in China. J. Clean. Prod. 2016, 112, 1700-1708. [CrossRef]

15. Li, F.; Wang, J. Estimation of carbon emission from burning and carbon sequestration from biochar producing using crop straw in China. Trans. CSAE 2013, 29, 1-7.

16. Awadhwal, N.; Thierstein, G. Soil crust and its impact on crop establishment: A review. Soil Tillage Res. 1985, 5, $289-302$. [CrossRef]

17. Vladimir, S.; Nora, P.; Halmo, S. Soil crust in agricultural land. Acta Fytotech. Zootech. 2014, 17, $109-114$.

18. Wang, L.; Coulter, J.A.; Palta, J.A.; Xie, J.; Luo, Z.; Li, L.; Carberry, P.; Li, Q.; Deng, X. Mulching-Induced Changes in Tuber Yield and Nitrogen Use Efficiency in Potato in China: A Meta-Analysis. Agronomy 2019, 9, 793. [CrossRef] 
19. Michelon, N.; Pennisi, G.; Myint, N.O.; Orsini, F.; Gianquinto, G. Strategies for Improved Water Use Efficiency (WUE) of Field-Grown Lettuce (Lactuca sativa L.) under a Semi-Arid Climate. Agronomy 2020, 10, 668. [CrossRef]

20. Wu, C.; Lu, W.; Chen, H.; Han, T.; Zhao, J.; Zhang, M.; Jiang, C.; Li, S.; Xu, R.; Zhang, L.; et al. A No-Tillage Seeding Practice of Summer Crop after Wheat. China Patent ZL201110378379.6, 1 April 2015.

21. National Bureau of Statistic of China. China Statistical Yearbook; China Statistics Press: Beijing, China, 2018.

22. Fehr, W.; Caviness, C. Stages of Soybean Development: Special Report 80, Iowa Agricultural Experiment Station, Iowa Cooperative External Series; Iowa State University: Ames, IA, USA, 1977.

23. Cui, Z.; Yue, S.; Wang, G.; Meng, Q.; Wu, L.; Yang, Z.; Zhang, Q.; Li, S.; Zhang, F.; Chen, X. Closing the yield gap could reduce projected greenhouse gas emissions: A case study of maize production in China. Glob. Chang. Biol. 2013, 19, 2467-2477. [CrossRef]

24. Xu, C.; Huang, S.; Tian, B.; Ren, J.; Meng, Q.; Wang, P. Manipulating Planting Density and Nitrogen Fertilizer Application to Improve Yield and Reduce Environmental Impact in Chinese Maize Production. Front. Plant Sci. 2017, 8, 1234. [CrossRef]

25. Kyei-Boahen, S.; Zhang, L. Early-Maturing Soybean in a Wheat-Soybean Double-Crop System Yield and Net Returns. Agron. J. 2006, 98, 295-301. [CrossRef]

26. Caviglia, O.P.; Sadras, V.O.; Andrade, F.H. Yield and Quality of Wheat and Soybean in Sole- and Double-Cropping. Agron. J. 2011, 103, 1081-1089. [CrossRef]

27. Seifert, C.; Lobell, D. Response of double cropping suitability to climate change in the United States. Environ. Res. Lett. 2015, 10, 024002. [CrossRef]

28. Wang, X.; Wu, C.; Qi, Y.; Xu, Z.; Wang, Z.; Han, T. Effects of straw management and sowing methods on soybean agronomic traits and soil physical properties. Sci. Agric. Sin. 2016, 49, 1453-1465.

29. Hansel, D.S.S.; Schwalbert, R.A.; Shoup, D.E.; Holshouser, D.L.; Parvej, R.; Prasad, P.V.; Ciampitti, I.A. A Review of Soybean Yield when Double-Cropped after Wheat. Agron. J. 2019, 111, 677-685. [CrossRef]

30. Roper, M.; Ward, P.; Keulen, A.; Hill, J. Under no-tillage and stubble retention, soil water content and crop growth are poorly related to soil water repellency. Soil Tillage Res. 2013, 126, 143-150. [CrossRef]

31. Peirone, L.S.; Irujo, G.A.P.; Bolton, A.; Erreguerena, I.; Aguirrezábal, L.A.N. Assessing the Efficiency of Phenotyping Early Traits in a Greenhouse Automated Platform for Predicting Drought Tolerance of Soybean in the Field. Front. Plant Sci. 2018,9 , 587. [CrossRef]

32. Zhao, Y.; Xu, C.; Yang, X.; Li, S.; Zhou, J.; Li, J.; Han, T.; Wu, C. Effects of sowing methods on seedling stand and production profit of summer soybean under wheat-soybean system. Crops 2018, 4, 114-120.

33. Karayel, D. Performance of a modified precision vacuum seeder for no-till sowing of maize and soybean. Soil Tillage Res. 2009, 104, 121-125. [CrossRef]

34. Zhao, H.; Wang, R.-Y.; Ma, B.-L.; Xiong, Y.-C.; Qiang, S.-C.; Wang, C.-L.; Liu, C.-A.; Li, F.-M. Ridge-furrow with full plastic film mulching improves water use efficiency and tuber yields of potato in a semiarid rainfed ecosystem. Field Crop Res. 2014, 161, 137-148. [CrossRef]

35. Wang, L.; Li, X.G.; Guan, Z.-H.; Jia, B.; Turner, N.C.; Li, F.-M. The effects of plastic-film mulch on the grain yield and root biomass of maize vary with cultivar in a cold semiarid environment. Field Crop Res. 2018, 216, 89-99. [CrossRef]

36. Chang, L.; Han, F.; Chai, S.; Cheng, H.; Yang, D.; Chen, Y. Straw strip mulching affects soil moisture and temperature for potato yield in semiarid regions. Agron. J. 2020, 112, 1126-1139. [CrossRef]

37. Deng, H.; Zhang, H.; Xiao, R.; Zhang, Y.; Tian, J.; Li, F.; Wang, Y.; Zhou, H.; Li, X. Effects of different covering planting patterns on soil moisture, temperature characteristics and maize yield in semi-arid region of the Loess Plateau. Sci. Agric. Sin. 2020, 53, 273-287.

38. Singh, C.B.; Singh, S.; Arora, V.K.; Sekhon, N.K. Residue Mulch Effects on Potato Productivity and Irrigation and Nitrogen Economy in a Subtropical Environment. Potato Res. 2015, 58, 245-260. [CrossRef]

39. Tuo, Y.; Fei, L.; Yang, L.; Zhang, Y. Simulation study on influence of straw mulch on soil moisture and heat of summer corn farmland. Trans. CSAE 2007, 23, 27-32.

40. Zribi, W.; Aragüés, R.; Medina, E.; Faci, J. Efficiency of inorganic and organic mulching materials for soil evaporation control. Soil Tillage Res. 2015, 148, 40-45. [CrossRef]

41. Yang, W.; Zhu, J.; Wu, Q.; Wang, Z.; Du, S. Growth and physiological metabolism characteristic of cotton seedlings under combination of waterlogging and heat stress. Trans. CSAE 2015, 31, 98-104.

42. Gao, Y.; Tao, H.; Zhu, J.; Huang, S.; Xu, C.; Sheng, Y.; Wang, P. Effects of wheat stubble height on growth and water use efficiency of mechanized sowing summer maize. Sci. Agric. Sin. 2015, 48, 3803-3810.

43. Cai, T.; Xu, H.; Peng, D.; Yin, Y.; Yang, W.; Ni, Y.; Chen, X.; Xu, C.; Yang, D.; Cui, Z.; et al. Exogenous hormonal application improves grain yield of wheat by optimizing tiller productivity. Field Crop Res. 2014, 155, 172-183. [CrossRef]

44. Sekhon, N.; Hira, G.; Sidhu, A.; Thind, S. Response of soyabean (Glycine max Mer.) to wheat straw mulching in different cropping seasons. Soil Use Manag. 2005, 21, 422-426. [CrossRef]

45. Dong, B.; Zheng, X.; Liu, H.; Able, J.A.; Yang, H.; Zhao, H.; Zhang, M.; Qiao, Y.; Wang, Y.; Liu, M. Effects of Drought Stress on Pollen Sterility, Grain Yield, Abscisic Acid and Protective Enzymes in Two Winter Wheat Cultivars. Front. Plant Sci. 2017, 8, 1008. [CrossRef]

46. Akhtar, K.; Wang, W.; Khan, A.; Ren, G.; Afridi, M.Z.; Feng, Y.; Yang, G. Wheat straw mulching offset soil moisture deficient for improving physiological and growth performance of summer sown soybean. Agric. Water Manag. 2019, 211, 16-25. [CrossRef] 
47. Dam, R.; Mehdi, B.; Burgess, M.; Madramootoo, C.; Mehuys, G.; Callum, I. Soil bulk density and crop yield under eleven consecutive years of corn with different tillage and residue practices in a sandy loam soil in central Canada. Soil Tillage Res. 2005, 84, 41-53. [CrossRef]

48. Liu, X.; Zhang, X.; Chen, S.; Sun, H.; Shao, L. Subsoil compaction and irrigation regimes affect the root-shoot relation and grain yield of winter wheat. Agric. Water Manag. 2015, 154, 59-67. [CrossRef]

49. Li, S.; Li, Q.-Q.; Wang, C.-Q.; Li, B.; Gao, X.-S.; Li, Y.-D.; Wu, D.-Y. Spatial variability of soil bulk density and its controlling factors in an agricultural intensive area of Chengdu Plain, Southwest China. J. Integr. Agric. 2019, 18, 290-300. [CrossRef]

50. Liu, Y.; Liu, Y.; Liu, H.; Shang, J.; Yu, C.; Lin, Q. Effects of straw returning amount on soil physical and chemical properties and yield of wheat. Chin. Sci. Bull. 2013, 29, 131-135.

51. Hu, C.; Zheng, C.; Sadras, V.O.; Ding, M.; Yang, X.; Zhang, S. Effect of straw mulch and seeding rate on the harvest index, yield and water use efficiency of winter wheat. Sci. Rep. 2018, 8, 8167. [CrossRef] [PubMed]

52. Kader, M.; Senge, M.; Mojid, M.; Ito, K. Recent advances in mulching materials and methods for modifying soil environment. Soil Tillage Res. 2017, 168, 155-166. [CrossRef]

53. Li, Q.; Li, H.; Zhang, L.; Zhang, S.; Chen, Y. Mulching improves yield and water-use efficiency of potato cropping in China: A meta-analysis. Field Crop Res. 2018, 221, 50-60. [CrossRef]

54. Kong, X.; Li, X.; Lu, H.; Li, Z.; Xu, S.; Li, W.; Zhang, Y.; Zhang, H.; Dong, H. Monoseeding improves stand establishment through regulation of apical hook formation and hypocotyl elongation in cotton. Field Crop Res. 2018, 222, 50-58. [CrossRef]

55. Bunna, S.; Sinath, P.; Makara, O.; Mitchell, J.; Fukai, S. Effects of straw mulch on mungbean yield in rice fields with strongly compacted soils. Field Crop Res. 2011, 124, 295-301. [CrossRef]

56. Cui, Y.-F.; Meng, J.; Wang, Q.-X.; Zhang, W.-M.; Cheng, X.-Y.; Chen, W.-F. Effects of straw and biochar addition on soil nitrogen, carbon, and super rice yield in cold waterlogged paddy soils of North China. J. Integr. Agric. 2017, 16, 1064-1074. [CrossRef]

57. He, L.-L.; Zhong, Z.-K.; Yang, H.-M. Effects on soil quality of biochar and straw amendment in conjunction with chemical fertilizers. J. Integr. Agric. 2017, 16, 704-712. [CrossRef]

58. Wang, Y.; Li, Z.; Han, B.; Shi, Z.; Ning, T.; Jiang, X.; Zheng, Y.; Bai, M.; Zhao, J. Effects of conservation tillage on soil microbial biomass and activity. Acta Ecol. Sin. 2007, 27, 3384-3390.

59. Zhang, S.-H.; Huang, J.; Luo, Z.-R.; Dong, S.; Wang, Y.-K.; Zhu, Q.-G.; Zhang, L.; Jin, A.-W. Effect of adding different amounts of wheat straw and phosphorus on soil microorganism community. J. Appl. Ecol. 2014, 25, 797-802.

60. Kuang, E.; Li, Z.; Chi, F.; Zhang, J.; Su, Q.; Zhu, B. Effect of different plough and organic fertilizer on characteristics of soybean yield and soil nutrients. Soybean Sci. 2020, 39, 108-115.

61. Smith, D.M.; Cusack, S.; Colman, A.W.; Folland, C.K.; Harris, G.R.; Murphy, J.M. Improved Surface Temperature Prediction for the Coming Decade from a Global Climate Model. Science 2007, 317, 796-799. [CrossRef] [PubMed]

62. Zhang, W.; Cao, G.; Li, X.; Zhang, H.; Wang, C.; Liu, Q.; Chen, X.; Cui, Z.; Shen, J.; Jiang, R.; et al. Closing yield gaps in China by em-powering smallholder farmers. Nature 2016, 537, 671-674. [CrossRef]

63. Chen, X.; Cui, Z.; Fan, M.; Vitousek, P.; Zhao, M.; Ma, W.; Wang, Z.; Zhang, W.; Yan, X.; Yang, J.; et al. Producing more grain with lower environmental costs. Nature 2014, 514, 486-489. [CrossRef]

64. Dai, J.; Dong, H. Intensive cotton farming technologies in China: Achievements, challenges and countermeasures. Field Crop Res. 2014, 155, 99-110. [CrossRef]

65. Dai, J.; Kong, X.; Zhang, D.; Li, W.; Dong, H. Technologies and theoretical basis of light and simplified cotton cultivation in China. Field Crop Res. 2017, 214, 142-148. [CrossRef] 